\title{
Approximating Phosphorus Release from Soils to Surface Runoff and Subsurface Drainage
}

\author{
R. W. McDowell and A. N. Sharpley*
}

\begin{abstract}
Phosphorus application in excess of crop needs has increased the concentration of $P$ in surface soil and runoff and led many states to develop P-based nutrient management strategies. However, insufficient data are available relating $P$ in surface soil, surface runoff, and subsurface drainage to develop sound guidelines. Thus, we investigated $P$ release from the surface $(0-5 \mathrm{~cm}$ depth) of a Denbigh silt loam from Devon, U.K. (30-160 $\mathrm{mg} \mathrm{kg}^{-1}$ Olsen P) and Alvin, Berks, Calvin, and Watson soils from Pennsylvania (10-763 $\mathrm{mg} \mathrm{kg}^{-1}$ Mehlich-3 $P$ ) in relation to the concentration of $P$ in surface runoff and subsurface drainage. A change point, where the slopes of two linear relationships between water- or $\mathrm{CaCl}_{2}$-extractable soil $\mathrm{P}$ and soil test phosphorus (STP) (Olsen or Mehlich-3) meet, was evident for the Denbigh at 33 to $36 \mathrm{mg} \mathrm{kg}^{-1}$ Olsen P, and the Alvin and Berks soils at 185 to $190 \mathrm{mg}$ Mehlich-3 $\mathrm{P} \mathrm{kg}^{-1}$. Similar change points were also observed when STP was related to the $P$ concentration of surface runoff $\left(185 \mathrm{mg} \mathrm{kg}^{-1}\right)$ and subsurface drainage $\left(193 \mathrm{mg} \mathrm{kg}^{-1}\right)$. The use of water and $\mathrm{CaCl}_{2}$ extraction of surface soil is suggested to estimate surface runoff $P$ ( $r^{2}$ of 0.92 for $\mathrm{UK}$ and 0.86 for $P A$ soils) and subsurface drainage $P$ ( $r^{2}$ of 0.82 for $U K$ and 0.88 for $P A$ soils), and to determine a change point in STP, which may be used in support of agricultural and environmental $P$ management.
\end{abstract}

$\mathrm{T}$ HE loss of phosphorus (P) from soil to surface runoff and subsurface drainage is of concern due to the resulting effect upon surface water quality (Foy and Withers, 1995; Sharpley et al., 2000). The continued application of fertilizers and manures in many areas has resulted in the buildup of soil $\mathrm{P}$ concentrations above those required for optimum plant growth. These elevated concentrations increase the potential for $\mathrm{P}$ loss. The loss of $\mathrm{P}$ in dissolved and particulate forms is a function of, but not exclusively of, topography, soil type, soil test phosphorus (STP) concentration, and soil hydrology. Measures to stop erosion can significantly decrease particulate and dissolved forms of P loss (Withers and Jarvis, 1998). However, decreasing dissolved P loss alone is much more difficult.

Over the past three decades much research has shown that the dissolved reactive phosphorus (DRP) concentration in surface runoff is related to STP concentration in the topsoil. For example, Pote et al. (1996) found that DRP concentration in surface runoff was linearly related to P extracted by Mehlich-3 ( $r^{2}$ of 0.72 ), Bray-I $\left(r^{2}\right.$ of 0.75$)$, Olsen $\left(r^{2}\right.$ of 0.72$)$, distilled water $\left(r^{2}\right.$ of $0.82)$, iron oxide paper $\left(r^{2}\right.$ of 0.82$)$, acidified ammonium oxalate $\left(r^{2}\right.$ of 0.85$)$, and $\mathrm{P}$ sorption saturation $\left(r^{2}\right.$ of

USDA-ARS, Pasture Systems and Watershed Management Research Unit, Curtin Road, Building 3702, University Park, PA 16802-3702. Received 22 May 2000. *Corresponding author (ans3@psu.edu).

Published in J. Environ. Qual. 30:508-520 (2001).
0.77). However, Sibbesen and Sharpley (1997) noted that if a wider range of STP concentrations was studied, linear relationships may become curvilinear at large STP concentrations due to the saturation of soil P-fixing sites.

Fewer studies have related concentrations of DRP in subsurface drainage to STP concentration. Smith et al. (1998) noted a curvilinear relationship between DRP concentration in drainage water from lysimeters of six soils from lowland England and Olsen P concentration in the topsoil (0 to $15 \mathrm{~cm}$ depth). Concentrations of DRP increased sharply at Olsen P concentrations in the soil greater than $70 \mathrm{mg} \mathrm{L}^{-1}$. Hanway and Laflen (1974) found a positive relationship between acid fluorideextractable $\mathrm{P}$ at depth and $\mathrm{P}$ in drainage water. Sharpley et al. (1977) showed that inorganic P in tile drainage was related to inorganic $\mathrm{P}$ extracted in $0.1 \mathrm{M} \mathrm{NaCl}$ extracts of soil from the 40- to 50-cm depth.

An overarching objective of this research is to evaluate the effectiveness of using STP data to predict P movement. However, to truly assess the potential for $\mathrm{P}$ loss, STP must be accompanied by a measure of desorbability that reflects the cation status as well as the ionic strength of the aqueous phase of the system (Beauchemin et al., 1996; Ryden and Syers, 1975). If soil testing data and methods can be used in water quality protection, appropriate criteria and upper STP thresholds have to be established. Little work has been done to identify what these thresholds should be. One approach may be to use a split-line model to determine a soil P threshold or change point that separates the relationship between STP and DRP in drainage waters into two sections, one with greater P loss per unit increase in STP than the other (Hesketh and Brookes, 2000; McDowell and Condron, 1999; McDowell and Trudgill, 2000). Effectively, the change point in a split line model represents an approximation of a curvilinear relationship such as a sorption isotherm, but more importantly it is designed as a management tool to estimate when in STP the potential risk of $\mathrm{P}$ loss increases. For example, in soils with an Olsen $\mathrm{P}$ concentration ranging from 10 to 120 $\mathrm{mg} \mathrm{kg}{ }^{-1}$, Heckrath et al. (1995) noted a change point at $60 \mathrm{mg} \mathrm{kg}{ }^{-1}$, above which DRP in drainage waters increased much more than if below.

The amount of $\mathrm{P}$ released from soil to water is dependent upon the soil P quantity-intensity relationship (Q/

\footnotetext{
Abbreviations: $\mathrm{CaCl}_{2}-\mathrm{P}, 0.01 M \mathrm{CaCl}_{2}$-extractable phosphorus; DPS degree of phosphorus saturation (\%); DRP, dissolved reactive phosphorus; $m_{1}$, slope of linear relationship between soil test phosphorus or degree of phosphorus saturation and phosphorus in drainage waters, surface runoff of $0.01 \mathrm{M} \mathrm{CaCl}_{2}$ for values of soil test phosphorus or degree of phosphorus less than the change point; $m_{2}$, difference in slopes after change point compared with $m_{1} ; \mathrm{Q} / \mathrm{I}$, quantity-intensity relationship; STP, soil test phosphorus.
} 
I) and the kinetics of $\mathrm{P}$ desorption. Many methods have been used to examine the kinetics of $\mathrm{P}$ desorption. For example, water or dilute salt solutions (the latter designed to simulate soil solution) have been used as desorption mediums at soil to water ratios ranging from 1:1 to $1: 1000$ to measure the amount of $P$ desorbed at different times (Sharpley et al., 1981; Elkhatib and Hern, 1988; Vig and Dev, 1979). These release small concentrations of $\mathrm{P}$, because the increase in solution concentration leads to the establishment of equilibrium. Freese et al. (1995) suggest, however, that true desorption kinetics may be masked due to the resorption of P. Alternative methods use P sinks such as anion exchange membranes, iron oxide strips, and iron oxide gels with water or dilute salt mediums to keep desorbed $\mathrm{P}$ in the medium small. These methods are intended to simulate the action of plant roots to sequester P (Cooperband and Logan, 1992). However, the kinetics may represent the $P$ sinks' greater ability to "pull" $\mathrm{P}$ out of solution and the soil than the unaided rate of $\mathrm{P}$ release into runoff. Consequently, each method must be used to meet the objectives of the study. Little work has been done to see if the $\mathrm{Q} / \mathrm{I}$ relationship changes due to the kinetics of $\mathrm{P}$ desorption over a wide range of STP concentrations in the same soil.

This paper evaluates four relationships:

(i) the effectiveness of using STP to predict the magnitude of soil P movement;

(ii) presence of a change point in STP versus soil solution $\mathrm{P}$ estimated from laboratory extracts of airdried soils;

(iii) presence of a change point in STP versus $\mathrm{P}$ in surface runoff;

(iv) presence of a change point in STP versus $\mathrm{P}$ in subsurface drainage waters.

In addition, the kinetics of the STP to soil solution P relationship in air-dried soils is examined to determine any variability with time and, in turn, the ability to determine a change point.

\section{MATERIALS AND METHODS}

\section{Field Settings}

Soils were collected from locations in the UK (January) and USA (April) in 1998:

(i) Slapton Wood, Devon (UK), a 9.5-ha subwatershed of Slapton Ley, the largest body of freshwater in southwest England. The soils are Denbigh silt loams (Typic Dystrudept) of permanent arable (in wheat, Triticum sp.) and grassland fields, which had received various quantities of mineral fertilizer and lime over 6 yr.

(ii) FD-36, Pennsylvania, a 39.5-ha subwatershed of Mahantango Creek, which is a tributary of the Susquehanna River and ultimately the Chesapeake Bay. The soils are Alvira (fine-loamy, mixed, mesic Aeric Fragiaquult), Berks (loamyskeletal, mixed, active, mesic Typic Dystrudept), Calvin (loamy-skeletal, mixed, mesic Typic Dystrochrept), and Watson (fine-loamy, mixed, mesic Typic Fragiudult) channery silt loams of cultivated fields (permanent arable, cultivated from soybean; Glycine max (L.) Merr.), that had received different fertilizer inputs and swine manure over the last 10 to $15 \mathrm{yr}$.

\section{Soil Sampling and Analyses}

Twenty-five topsoil $(0-7.5 \mathrm{~cm})$ samples each of the Berks, Calvin, and Watson soils were taken, along with 15 samples of the Alvira soils (from soil survey map). A total of 25 arable and 18 grassland topsoil samples were taken of the Denbigh soils at Slapton Wood (from soil survey map). Samples were taken from fields with known manurial histories so a wide range of STP concentrations could be covered. Soils were analyzed for $\mathrm{pH}$ in water, organic $\mathrm{C}\left(\mathrm{g} \mathrm{kg}^{-1}\right)$, STP (Mehlich-3 $\mathrm{P}$ and/or Olsen $\mathrm{P}$ ), water, and $0.01 \mathrm{M} \mathrm{CaCl}_{2}$-extractable $\mathrm{P}$ by methods described below.

\section{Subsurface Drainage Study}

A total of sixteen lysimeters $(25 \mathrm{~cm}$ i.d., $30 \mathrm{~cm}$ deep) were collected of Denbigh soils from the Slapton Wood watershed (described above) in summer 1998 and taken to an outdoor facility at Cambridge University, Cambridge (UK). This included eight arable lysimeters (30-95 mg Olsen $\mathrm{P} \mathrm{kg}^{-1}$ [determined at 0-7.5 cm]) and eight grassland lysimeters (30-160 $\mathrm{mg}$ Olsen $\mathrm{P} \mathrm{kg}^{-1}$ [determined at 0-7.5 cm]). Another 54 lysimeters $(15 \mathrm{~cm}$ i.d., $30 \mathrm{~cm}$ deep; 18 Berks, 12 Alvira, 10 Calvin, and 14 Watson soils; $10-763 \mathrm{mg}$ Mehlich-3 $\mathrm{P} \mathrm{kg}^{-1}$, equivalent to $2-153 \mathrm{mg}$ Olsen $\mathrm{P} \mathrm{kg}^{-1}$ [determined at $0-7.5 \mathrm{~cm}$ ]) were collected in summer 1999 of soils from the FD-36 watershed and taken to an outdoor facility at University Park, Pennsylvania. Lysimeters were taken by driving a PVC pipe into the dry soil with one stroke of a 2-Mg drop-hammer. The inside of the pipe was coated with paraffin wax to seal between the soil and lysimeter. More wax was placed at the bottom to give a more even distribution when driving it into the soil. Additional edge flow restriction would be gained by the swelling action of dry soil when wetted. Acid-washed sand was used to fill any void space (less than $1 \mathrm{~cm}$ ) between the soil and base cap. A 1-cm-diam. hole was drilled in the base cap, a small 5-cm tube glued in its place, and glass wool inserted to prevent any loss of sand.

Drainage waters were collected in response to rainfall (tap water, $\mathrm{P}$ less than detection limit of $\left.0.005 \mathrm{mg} \mathrm{P} \mathrm{L}^{-1}\right)$ of 10 $\mathrm{mm} \mathrm{h}^{-1}$ for $30 \mathrm{~min}$, filtered $(<0.45 \mu \mathrm{m})$, and stored at $4^{\circ} \mathrm{C}$ up to $7 \mathrm{~d}$ in the dark until analysis. The lysimeters were sampled $(0-7.5 \mathrm{~cm}$ depth $)$ at the end of the experiment and analyzed for $\mathrm{pH}$ in water, organic C, STP (Mehlich-3 P and/or Olsen $\mathrm{P})$, water, and $0.01 \mathrm{M} \mathrm{CaCl}_{2}-$ extractable $\mathrm{P}$.

\section{Surface Runoff Study}

Soils from 72 sites were taken in 1999 from cultivated fields (3 Alvira, 35 Berks, 11 Calvin, and 23 Watson) from the FD36 watershed. Soils were air-dried, sieved $(<2 \mathrm{~mm})$, and packed into impermeable boxes $(15 \mathrm{~cm}$ wide, $15 \mathrm{~cm}$ deep, 100 $\mathrm{cm}$ long) to a bulk density of $1.2 \mathrm{~g} \mathrm{~cm}^{-3}$. Surface runoff was generated by applying rainfall (tap water, $\mathrm{P}$ less than detection limit of $0.005 \mathrm{mg} \mathrm{P} \mathrm{L}{ }^{-1}$ ) at $50 \mathrm{~mm} \mathrm{~h}^{-1}$ for $30 \mathrm{~min}$ to each boxed soil, which was set to have a $5 \%$ slope. All rainfall was produced with size, velocity, and impact angles approximating natural rainfall (Shelton et al., 1985). Samples of runoff from eight grassland and eight cultivated soils at Slapton were collected in the field by driving a $15-\mathrm{cm}$-wide, 7.5-cm-deep, 100$\mathrm{cm}$-long box into the soil with a hammer and raining on them for $30 \mathrm{~min}$ at an intensity of $50 \mathrm{~mm} \mathrm{~h}^{-1}$. All boxes at the Slapton Wood (Denbigh soils) field site were on an approximate $5 \%$ slope. Prior to runoff generation, $\mathrm{pH}$ in water, organic $\mathrm{C}$, STP (Mehlich-3 $\mathrm{P}$ and/or Olsen $\mathrm{P}$ ), water, and $0.01 \mathrm{M} \mathrm{CaCl}_{2}$ extractable $\mathrm{P}$ were determined in the top 0 to $7.5 \mathrm{~cm}$ of soil from each box. Holes were plugged with replacement soil 
from immediately outside the sampled area. Subsamples of the first $250 \mathrm{~mL}$ of surface runoff and of all surface runoff combined (first $250 \mathrm{~mL}$ plus the remaining volume, usually $6 \mathrm{~L})$ were filtered $(<0.45 \mu \mathrm{m})$, stored at $4^{\circ} \mathrm{C}$ in the dark, and analyzed within $1 \mathrm{wk}$.

\section{Soil, Surface Runoff, and Subsurface Drainage Analyses}

All soils were air-dried and ground to $<2 \mathrm{~mm}$ prior to analysis. Organic C was determined by ignition (Grewal et al., 1991) and soil $\mathrm{pH}$ in water using a soil to solution ratio of 1:2.5. Olsen $\mathrm{P}$ was extracted using a soil to solution ratio of 1:20 and $30 \mathrm{~min}$ end-over-end shaking (Olsen et al., 1954, p. 1-19), while a ratio of 1:5 was used for $0.01 M \mathrm{CaCl}_{2}$ $\left(\mathrm{CaCl}_{2}-\mathrm{P}\right)$ and water-extractable $\mathrm{P}$, also with 30 min end-overend shaking (Schofield, 1955). Soil extractions with $0.01 \mathrm{M}$ $\mathrm{CaCl}_{2}$ are designed to reflect soil solution on the basis that cation exchange is minimized by the use of calcium and chloride at this concentration, which has no specific replacing power (Schofield, 1955). Mehlich-3 P, as the standard STP method in Pennsylvania, was determined (Mehlich, 1984). Dissolved reactive $\mathrm{P}$, commonly assumed to be inorganic $\mathrm{P}$, was measured in filtered $(<0.45 \mu \mathrm{m})$ soil extracts, surface runoff, and subsurface drainage samples according to the method of Murphy and Riley (1962). Calcium $\left(\mathrm{Ca}^{2+}\right)$ was determined in the filtered surface runoff subsamples by ion exchange chromatography. Suspended sediment was measured on unfiltered surface runoff subsamples by weight after filtration through a $0.45-\mu \mathrm{m}$ filter.

Total $\mathrm{Al}, \mathrm{Fe}$, and $\mathrm{P}$ in the acid ammonium oxalate extracts (McKeague and Day, 1966) were analyzed by inductively coupled plasma spectrometry, and the percent degree of phosphorus saturation $(\%$ DPS $)$ calculated as $100 \times\left(\mathrm{mmol} \mathrm{kg}^{-1}\right.$ $\left.\mathrm{P} / 0.5\left[\mathrm{mmol} \mathrm{kg}^{-1} \mathrm{Al}+\mathrm{Fe}\right]\right)$ (Breeuwsma and Silva, 1992).

Due to the small number of samples, the kinetics of desorption was studied with three replicates in 8 Alvira, 11 Berks, and 25 Denbigh arable soils by determining $\mathrm{P}$ extracted by water or $0.01 M \mathrm{CaCl}_{2}$ (1:5 soil to solution ratio) after 2, 10, $30,120,300$, and $1440 \mathrm{~min}$. A preliminary analysis of the data fitted to first-order (Chien and Clayton, 1980), second-order (Chien and Clayton, 1980), parabolic diffusion (Vig and Dev, 1979), and an expanded Elovich equation (Polyzopoulos et al., 1986) showed that the best fits were obtained using the expanded Elovich equation:

$$
Q=[\ln (a b)+\ln (t+c)] / b
$$

where $Q=$ amount $\left(\mathrm{mg} \mathrm{kg}^{-1}\right)$ of released $\mathrm{P}$ at time $t(\mathrm{~min})$ and $a, b$, and $c$ are constants.

\section{Statistical Analyses}

The relationship and change point between $\mathrm{CaCl}_{2}-\mathrm{P}$ and STP (or percent DPS) was determined using a split-line model that describes two linear relationships whose slopes are significantly different from each other (at $P<0.05$ ), either side of a change point. Below the change point:

$$
\mathrm{CaCl}_{2}-\mathrm{P}=m_{1}(\mathrm{STP})+c
$$

and above the change point:

$$
\begin{aligned}
\mathrm{CaCl}_{2} & -\mathrm{P}=m_{1}(\mathrm{STP}) \\
& +m_{2}(\mathrm{STP}-\text { change point in STP })+c
\end{aligned}
$$

where $c$ is the intercept, $m_{1}$ is the slope of the linear relationship for values of STP (or percent DPS) less than the change point, and $m_{2}$ is the difference in slopes after the change point compared with $m_{1}$. The four parameters $\left(m_{1}, m_{2}\right.$, STP change point, and $c$ ) were estimated by nonlinear regression, using the method of maximum likelihood in Genstat v. 5.0 (Genstat 5 Committee, 1995). In general, the standard error of the change point was $10 \%$ or less. Hence, the estimates are reasonably precise. This can be attributed to the simple nature of the model to which all data points contribute toward the generation of the two slopes and where they meet to yield the change point. In all but two cases (see Fig. 7), more variance $\left(r^{2}\right)$ was accounted for by fitting the split-line model than by a simple linear regression.

The expanded Elovich equation was fitted using nonlinear regression in SPSS v. 6.0 (SPSS, 1993) and the fit assessed through a linear plot of observed versus predicted values giving an $r^{2}$ value. The $r^{2}$ value is given because nonlinear regression does not yield true $R^{2}$ values. All additional analyses (e.g., mean and standard error) were calculated using SPSS v. 6.0

\section{RESULTS AND DISCUSSION Soil Samples}

Organic $\mathrm{C}, \mathrm{pH}$ in water, and the concentrations of Olsen $\mathrm{P}$, Mehlich-3 $\mathrm{P}$, and $\mathrm{CaCl}_{2}-\mathrm{P}$ for those soils used are given in Table 1 . The mean $\mathrm{pH}$ of the Denbigh arable soil was greater than the Denbigh grassland soil, while the inverse was true of organic $\mathrm{C}$. The range of Olsen $\mathrm{P}$ and $\mathrm{CaCl}_{2}-\mathrm{P}$ concentrations was similar in the Denbigh arable and grassland soils. The four soils in FD36 exhibited a wide range in Mehlich-3 $\mathrm{P}$ and $\mathrm{CaCl}_{2}-\mathrm{P}$ concentrations (Table 1). A change point becomes apparent for each soil by simply plotting these data (Fig.

\begin{tabular}{|c|c|c|c|c|c|}
\hline Site & Organic C & pH & Olsen P & Mehlich-3 P & $\mathrm{CaCl}_{2}-\mathbf{P}$ \\
\hline & $\mathbf{g ~ k g}^{-1}$ & & $\mathbf{m g} P \mathbf{k g}^{-1}$ & $\mathbf{m g ~ k g ^ { - 1 }}$ & $\operatorname{mg} \mathbf{P} \mathbf{L}^{-1}$ \\
\hline Denbigh arable & $33(2) \dagger$ & $6.0(0.1)$ & $30(3.2)$ & ndt & $0.11(0.016)$ \\
\hline$w$ & $15-48$ & $5.4-6.4$ & $6-60$ & - & $0.04-0.33$ \\
\hline Denbigh grassland & 49 (3) & $5.6(0.1)$ & $21(3.5)$ & nd & $0.08(0.011)$ \\
\hline$w$ & 12-78 & 4.7 (6.1) & 4-55 & - & $0.03-0.20$ \\
\hline Alvira & 20 (10) & $5.9(0.1)$ & $36(6.9)$ & $162(20)$ & $0.37(0.080)$ \\
\hline$w$ & 11-35 & $5.4-6.2$ & 11-82 & 8-236 & $0.09-0.92$ \\
\hline Berks & $15(9)$ & $6.4(0.1)$ & $44(3.6)$ & 185 (21.4) & $0.63(0.100)$ \\
\hline$w$ & 9-32 & $4.7-7.2$ & $8-71$ & $16-553$ & $0.06-2.73$ \\
\hline Calvin & $9(9)$ & $6.6(0.1)$ & $55(5.3)$ & 254 (28.7) & $1.23(0.200)$ \\
\hline$w$ & 5-20 & $6.2-7.1$ & 25-114 & $51-470$ & $0.36-5.63$ \\
\hline Watson & $26(12)$ & $6.3(0.1)$ & $45(4.9)$ & $193(28.5)$ & $0.38(0.1)$ \\
\hline$w$ & $15-53$ & $5.8-6.7$ & 34-108 & 45-489 & $0.09-1.22$ \\
\hline
\end{tabular}
1). Above the change point value, $\mathrm{CaCl}_{2}-\mathrm{P}$ increases at

Table 1. Means and range $(w)$ of organic $\mathrm{C}$, pH, and concentrations of Olsen $\mathrm{P}$ and Mehlich-3 P for Slapton Wood (Denbigh) and FD36 (Alvira, Berks, Calvin, and Watson) soils.

$\dagger \pm$ standard error.

+ nd $=$ not determined. 


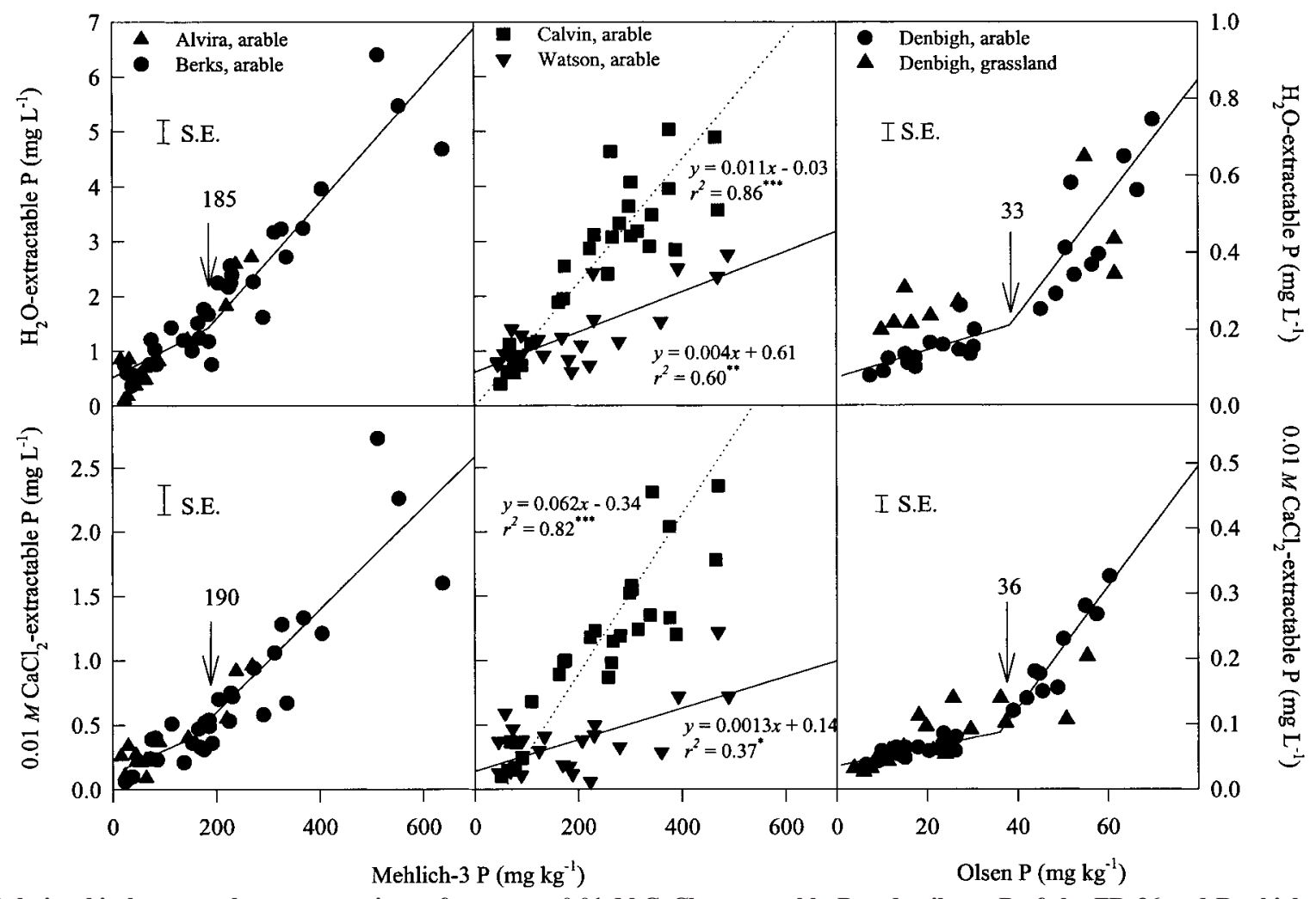

Fig. 1. Relationship between the concentrations of water- or $0.01 M \mathbf{C a C l}_{2}-\mathbf{e x t r a c t a b l e} \mathbf{P}$ and soil test $\mathbf{P}$ of the FD-36 and Denbigh grassland and arable soils. The change point is indicated by the arrow. $r^{2}$ is the coefficient of determination. S.E. is the standard error.

a greater rate per unit increase in STP than below this value. The value of the change point was $190 \mathrm{mg}$ Mehlich-3 $\mathrm{P} \mathrm{kg}^{-1}$ for the $0.01 \mathrm{M} \mathrm{CaCl}_{2}$ extraction and at 185 mg Mehlich-3 $\mathrm{P} \mathrm{kg}^{-1}$ for the water extraction for both Alvira and Berks soils individually or pooled together as one data set. Previous evidence has shown change points differ if the soil is in arable or grassland management (McDowell and Condron, 1999). Consequently, the Denbigh soil was split into two data sets (grassland and arable). No change point could be determined in the Calvin, Watson, or Denbigh grassland soils. This may be due to scatter in the data or simply because the soils were not sufficiently saturated with $\mathrm{P}$ to exhibit a change point.

\section{Kinetics and the Quantity-Intensity Relationship}

Organic $\mathrm{C}, \mathrm{pH}$ in water, and the concentrations of Olsen P, Mehlich-3 P, and $\mathrm{CaCl}_{2}-\mathrm{P}$ for those soils used in the kinetic study are given in Table 2. Soils were

Table 2. Means and range $(w)$ of organic $\mathrm{C}, \mathrm{pH}$, and concentrations of Olsen $P$ and Mehlich-3 P for Slapton Wood (Denbigh) and FD-36 (Alvira and Berks) soils used for desorption kinetics in water and $0.01 M \mathrm{CaCl}_{2}$.

\begin{tabular}{|c|c|c|c|c|}
\hline Site & Organic C & pH & Olsen $\mathbf{P}$ & Mehlich-3 P \\
\hline & \multicolumn{2}{|l|}{$\mathbf{g ~ k g}^{-1}$} & \multicolumn{2}{|c|}{$\longrightarrow \operatorname{mg~P~} \mathbf{k g}^{-1}$} \\
\hline Denbigh, arable & $34(2) \dagger$ & $6.2(0.2)$ & 31 (4.3) & nd \\
\hline$w$ & 30-50 & $5.4-6.4$ & $10-56$ & - \\
\hline Alvira, arable & nd & $6.0(0.1)$ & $21(2.1)$ & $162(20)$ \\
\hline$w$ & - & $5.7-6.3$ & $2-42$ & 8-236 \\
\hline Berks, arable & nd & $6.2(0.1)$ & $38(3.4)$ & $224(45)$ \\
\hline$w$ & - & $5.5-6.6$ & $5-102$ & 14-624 \\
\hline
\end{tabular}

$\dagger \pm$ standard error.

+ nd $=$ not determined. selected, from those with sufficient sample volume remaining, to have a range of values and means similar to those in Table 1. The relationship between STP concentration and $\mathrm{P}$ desorption ( $\mathrm{P}$ intensity: water- and $0.01 M \mathrm{CaCl}_{2}$-extractable $\mathrm{P}$ ) per minute for Alvira, Berks, and Denbigh arable soils is shown in Fig. 2 and 3. More $\mathrm{P}$ was desorbed in water than in $0.01 \mathrm{M} \mathrm{CaCl}$. This concurs with the results of Evans and Sorensen (1986), who showed that P desorption and loss by drainage water was inversely related to ionic strength.

More $\mathrm{P}$ was desorbed per minute with increasing STP concentration (Fig. 2). A change point in STP was still evident in all soils after $30 \mathrm{~min}$ and $24 \mathrm{~h}$ when using $0.01 \mathrm{M} \mathrm{CaCl}_{2}$ as an extractant (Fig. 2). However, change points in STP concentration were absent from the Alvira and Berks arable soils and the Denbigh arable soil after $24 \mathrm{~h}$ using water as the desorption medium (Fig. 3). This suggests that $0.01 M \mathrm{CaCl}_{2}$ and water extract $\mathrm{P}$ from different pools with time. Raven and Hossner (1994) found that the relationship between the amounts of $\mathrm{P}$ added and the quantities and rates of $\mathrm{P}$ desorption followed a linear trend. Conversely, Lookman et al. (1995) found that P desorption in water could be separated into fast and slow desorption pools and that the relative size of the quickly desorbing pool increased with the initial degree of $\mathrm{P}$ saturation, effectively giving a change point in percent DPS.

A similar conclusion, but for STP, can be drawn from Fig. 4, which shows two examples of DRP desorption kinetics curves for two Berks soils, one on either side of the change point. For the soil above the change point an extrapolation of the Elovich equation fitted to de- 

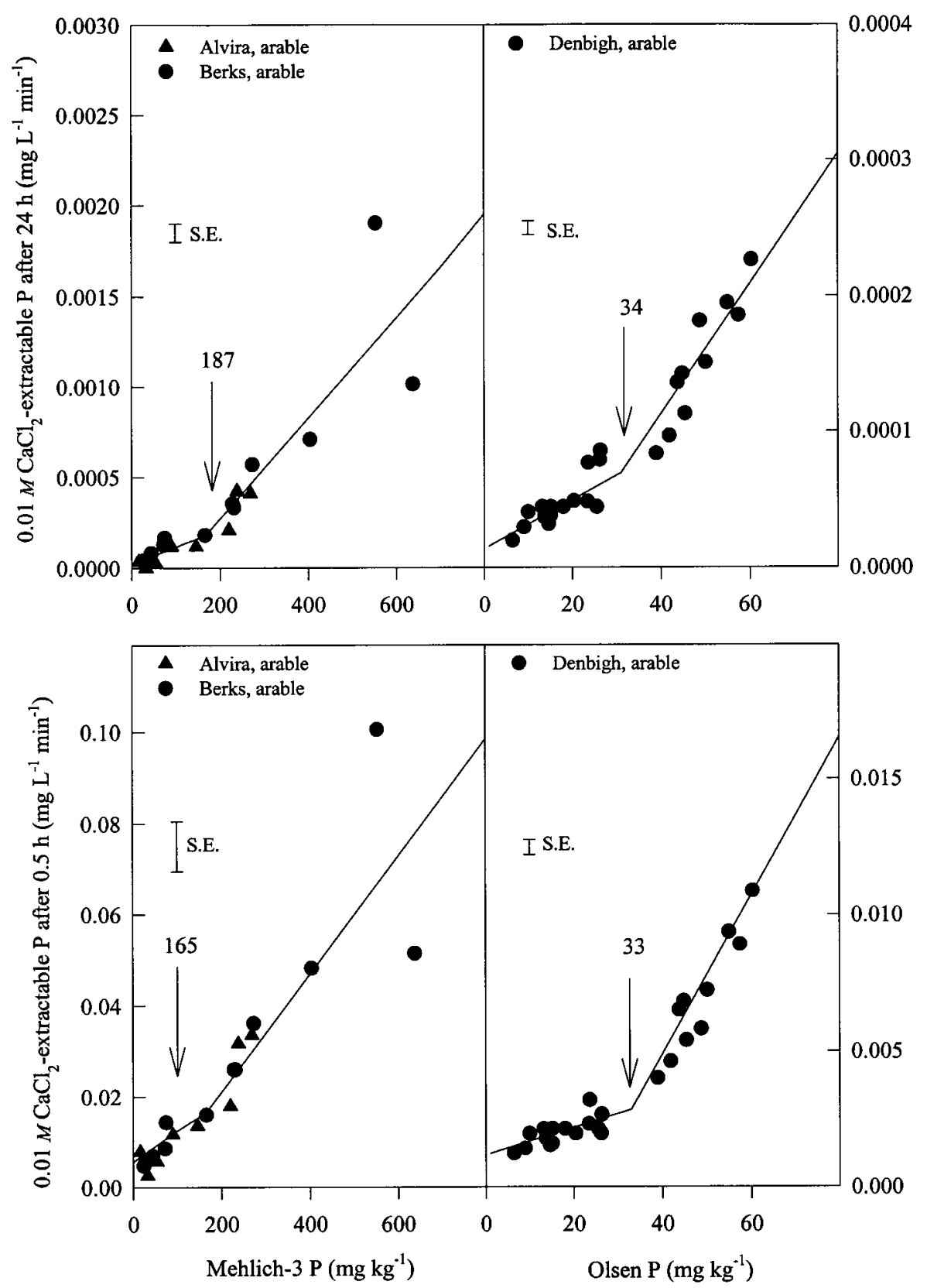

Fig. 2. Relationship between the rate of $0.01 \mathrm{M} \mathrm{CaCl}_{2}-$ extractable $\mathrm{P}$ concentration after $30 \mathrm{~min}$ or $24 \mathrm{~h}$ and soil test phosphorus (STP) concentration for Alvira, Berks, and Denbigh arable soils. The change point is indicated by the arrow. S.E. is the standard error.

sorption data for up to 30 min desorbs more $\mathrm{P}$ than the Elovich equation fitted to the desorption data for up to $24 \mathrm{~h}$. For the soil below the change point there is almost no difference between the curves. The ratio, concentration of desorbed $\mathrm{P}$ in water $\min ^{-1}$ after $24 \mathrm{~h}$ and Mehlich-3 $\mathrm{P}$ concentration, is similar between soils, indicating a linear relationship (0.0144 and 0.0141 for 73 and $404 \mathrm{mg} \mathrm{kg}^{-1}$ soils, respectively), whereas the ratio is different in $0.01 \mathrm{M} \mathrm{CaCl}_{2}$, suggesting a change point (0.0068 and 0.0042 for 73 and $404 \mathrm{mg} \mathrm{kg}^{-1}$ soils, respectively). The ratio (concentrations of desorbed $\mathrm{P}$ to Mehlich-3 P) is different for both soils and extractants if desorbed $\mathrm{P}$ is calculated from the Elovich equation fitted to data up to $30 \mathrm{~min}(0.0143$ and 0.0155 for 73 and $404 \mathrm{mg} \mathrm{kg}{ }^{-1}$ soils desorbed in water and 0.0069 and
0.0046 for 73 and $404 \mathrm{mg} \mathrm{kg}^{-1}$ soils desorbed in $0.01 \mathrm{M}$ $\mathrm{CaCl}_{2}$ ). Assuming that this curve represents a measure of the quickly desorbing $\mathrm{P}$ pool, it is apparent that this pool influences the change point after $30 \mathrm{~min}$ and that a different pool affects $\mathrm{P}$ desorption in water over longer periods (e.g., $24 \mathrm{~h}$ ).

\section{Subsurface Drainage}

Data for organic $\mathrm{C}, \mathrm{pH}$ in water, and concentrations of Olsen $\mathrm{P}$, Mehlich-3 $\mathrm{P}$, and $\mathrm{CaCl}_{2}-\mathrm{P}$ for soils used in the lysimeter evaluation of $\mathrm{P}$ movement through soil are given in Table 3. Mean values of each parameter are similar to those measured for the $\mathrm{Q} / \mathrm{I}$ relationships in Table 1, except for the Denbigh grassland lysimeters, which had mean Olsen $\mathrm{P}$ and $\mathrm{CaCl}_{2}-\mathrm{P}$ concentrations 

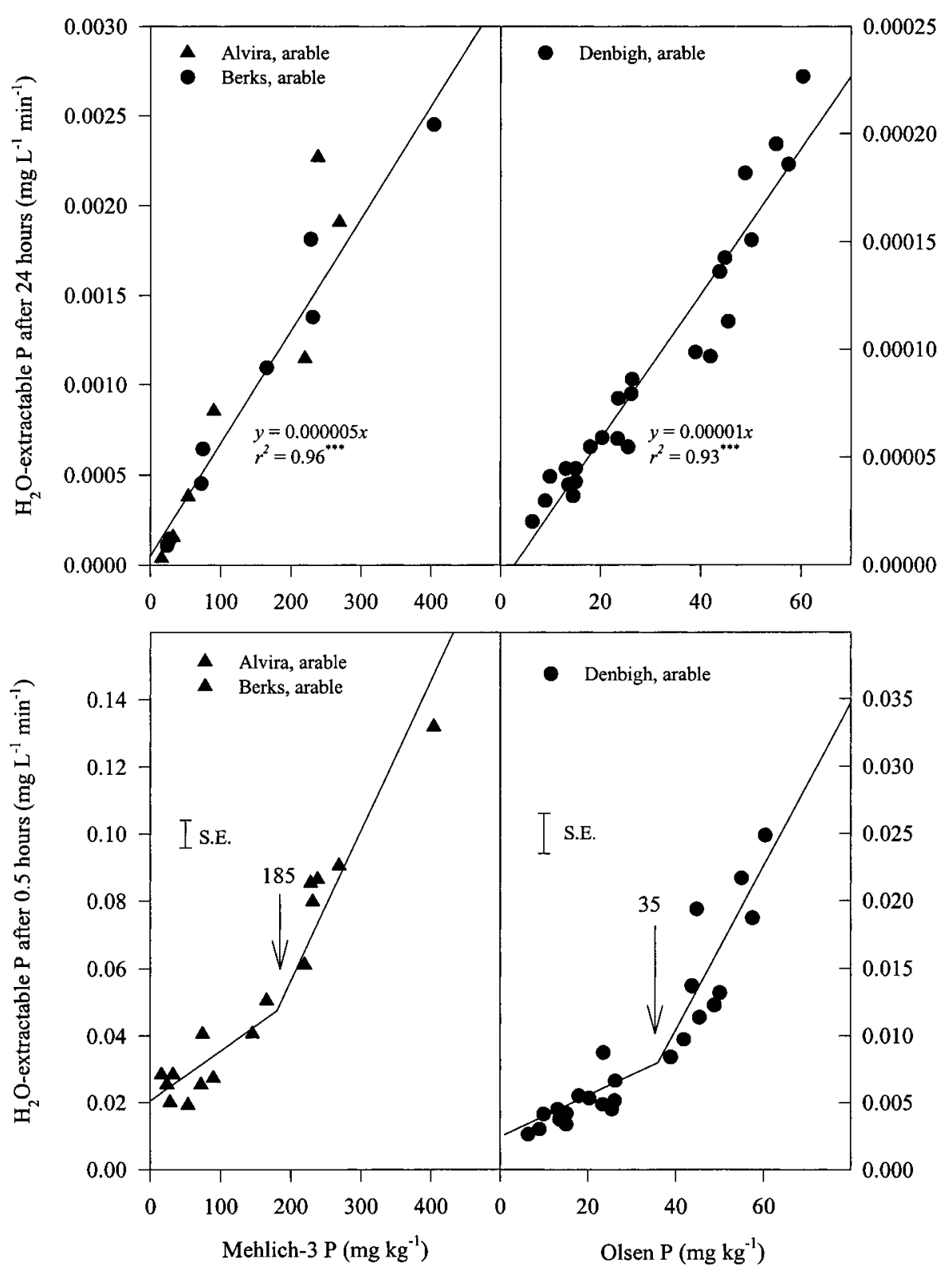

Fig. 3. Relationship between the rate of water-extractable $P$ concentration extracted after 30 min or 24 h and soil test phosphorus (STP) concentration for Alvira, Berks, and Denbigh arable soils. The change point is indicated by the arrow. $r^{2}$ is the coefficient of determination. S.E. is the standard error.

greater than those in Table 1. Throughout the experiment, infiltration capacity was not exceeded during any rainfall event, meaning no ponding occurred.

Arable and grassland Denbigh soil lysimeters ranged in Olsen $\mathrm{P}$ concentration $(0-7.5 \mathrm{~cm})$ from 44 to $112 \mathrm{mg} \mathrm{P}$ $\mathrm{kg}^{-1}$ and 33 to $161 \mathrm{mg} \mathrm{P} \mathrm{kg}^{-1}$, respectively. In the arable lysimeters, $\mathrm{CaCl}_{2}-\mathrm{P}$ concentrations of soil samples collected adjacent to the lysimeters were generally smaller than DRP concentrations in drainage water, while the opposite trend was evident in the grassland lysimeters (compare Fig. 1 and 5). This may reflect differences in the amount, turnover, and release of microbial $\mathrm{P}$ during wetting and drying cycles or more $\mathrm{P}$ derived from organic matter in the grassland soils than arable soils (Birch, 1964). Soil concentrations of Olsen P in the arable lysimeters were greater than the change point determined for this soil by a plot of the concentration of $\mathrm{CaCl}_{2}-\mathrm{P}$ against Olsen $\mathrm{P}\left(37 \mathrm{mg} \mathrm{P} \mathrm{kg}{ }^{-1}\right)$. It is clear that there was a direct relationship between drainage water DRP concentration, similar in shape to $\mathrm{CaCl}_{2}-\mathrm{P}$, and Olsen P concentration (Fig. 1 and 5).

The DRP concentration of lysimeter drainage waters from Alvira and Berks soils exhibited a change point in Mehlich-3 P concentration at $193 \mathrm{mg} \mathrm{kg}^{-1}$, very similar to that exhibited by the field soils at $190 \mathrm{mg}$ Mehlich-3 $\mathrm{P} \mathrm{kg}^{-1}$ when plotted against $\mathrm{CaCl}_{2}-\mathrm{P}$ (Fig. 5a). These results provide evidence for the increased loss of DRP in drainage water and $\mathrm{CaCl}_{2}-\mathrm{P}$ once the change point in STP is reached. Similarly, Hesketh and Brookes (2000) found that lysimeters of two arable soils gave a similar change point in Olsen $\mathrm{P}$ concentrations against DRP in drainage waters as against $\mathrm{CaCl}_{2}-\mathrm{P}$. Results 


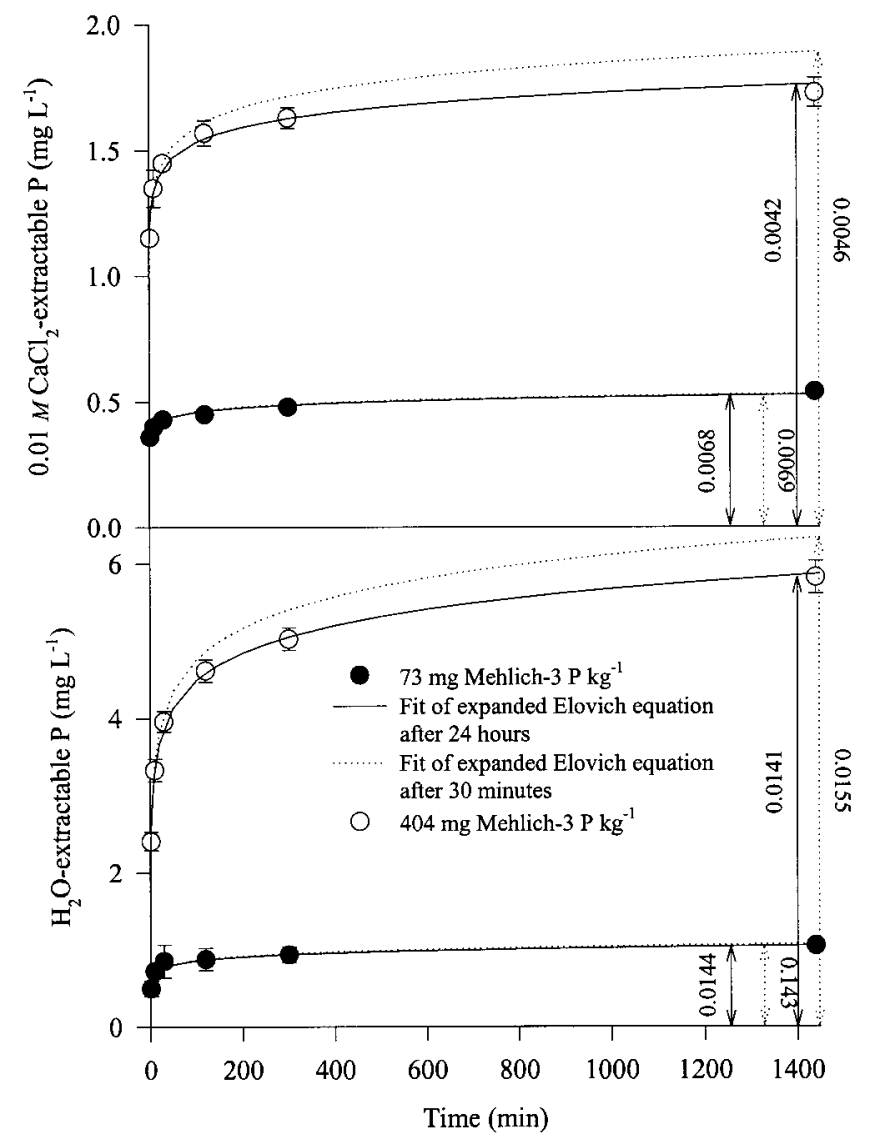

Fig. 4. Phosphorus desorption ( $\leq$ standard error [I]) with time for two Berks arable soils, fitted to the expanded Elovich equation using desorption data up to $30 \mathrm{~min}$ (dashed line) and up to $24 \mathrm{~h}$ (solid line) in $0.01 \mathbf{M ~ C a C l}_{2}$ and water. Numbers written vertically refer to the ratio of concentrations of $0.01 M \mathrm{CaCl}_{2}-$ or water-extractable $\mathrm{P}$ to soil test phosphorus (STP) after $30 \mathrm{~min}$ and $24 \mathrm{~h}$.

from the Calvin and Watson soils were more variable. However, concentrations of DRP in drainage waters were very similar to the concentration of $\mathrm{CaCl}_{2}-\mathrm{P}$ extracted from field soils. Indeed, a plot of DRP concentrations in drainage water against $\mathrm{CaCl}_{2}-\mathrm{P}$ for the $\mathrm{FD}$ 36 and Denbigh soils showed that both variables were significantly related to one another and of similar concentration (slope near to 1, Fig. 6). For these soils, a soil to solution (as $0.01 M \mathrm{CaCl}_{2}$ ) ratio of 1 to 5 , in conjunction with STP, may predict the change point in STP concentration, and estimate DRP concentration in drainage waters. However, it is widely known that the concentration of $\mathrm{P}$ in laboratory extracts varies with the soil to solution ratio, temperature, shaking, and soil chemistry (Barrow and Shaw, 1979), consequently $\mathrm{CaCl}_{2}-\mathrm{P}$ at this ratio requires further testing as an estimator for DRP in drainage water from other soils.

\section{Surface Runoff}

Data for the mean concentrations and range of organic $\mathrm{C}, \mathrm{pH}$ in water, and concentrations of Olsen $\mathrm{P}$, Mehlich-3 $\mathrm{P}$, and $\mathrm{CaCl}_{2}-\mathrm{P}$ in the soil used to evaluate soil $\mathrm{P}$ transfer to surface runoff are given in Table 4.

Table 3. Means and range ( $w$ ) organic $\mathrm{C}$, $\mathrm{pH}$, and concentrations of Olsen $\mathrm{P}$, Mehlich-3 $\mathrm{P}$, and $\mathrm{CaCl}_{2}-\mathrm{P}$ for the Slapton Wood (Denbigh) and FD-36 (Alvira, Berks, Calvin, and Watson) lysimeters.

\begin{tabular}{|c|c|c|c|c|c|}
\hline Site & Organic C & pH & Olsen $\mathbf{P}$ & Mehlich-3 P & $\mathrm{CaCl}_{2}-\mathbf{P}$ \\
\hline \multicolumn{3}{|c|}{$\mathrm{g} \mathrm{kg}^{-1}$} & \multicolumn{2}{|c|}{$\mathrm{mg} \mathrm{P} \mathrm{kg}^{-1}$} & $\operatorname{mg} \mathbf{P} \mathbf{L}^{-1}$ \\
\hline Denbigh arable & $35(2) \dagger$ & $6.2(0.1)$ & 48 (4.3) & nd $\$$ & $0.28(0.020)$ \\
\hline$w$ & 29-52 & $5.6-6.6$ & 4-76 & - & $0.08-0.55$ \\
\hline Denbigh grassland & $55(6)$ & $5.4(0.2)$ & $71(9.7)$ & nd & $0.35(0.020)$ \\
\hline$w$ & 34-85 & $5.1-5.7$ & 41-153 & - & $0.26-0.97$ \\
\hline Alvira arable & $32(6)$ & $6.0(0.1)$ & $36(6.9)$ & $166(30)$ & $0.40(0.070)$ \\
\hline$w$ & 13-62 & $5.6-6.3$ & 11-82 & $11-313$ & $0.09-0.82$ \\
\hline Berks arable & $44(6)$ & $6.3(0.1)$ & $44(3.6)$ & $244(44)$ & $0.53(0.080)$ \\
\hline$w$ & 14-70 & $5.4-6.8$ & 8-71 & $51-674$ & $0.06-1.34$ \\
\hline Calvin arable & $36(6)$ & $6.6(0.3)$ & $55(5.3)$ & $281(63)$ & $0.47(0.080)$ \\
\hline$w$ & 15-66 & $5.2-7.2$ & 25-114 & $76-766$ & $0.02-1.35$ \\
\hline Watson arable & 27 (7) & $6.3(0.1)$ & 45 (4.9) & 149 (35) & $0.22(0.70)$ \\
\hline$w$ & 12-59 & $5.6-6.5$ & $34-108$ & $10-495$ & $0.02-0.84$ \\
\hline
\end{tabular}

$\dagger \pm$ standard error.

$\neq$ nd $=$ not determined. 


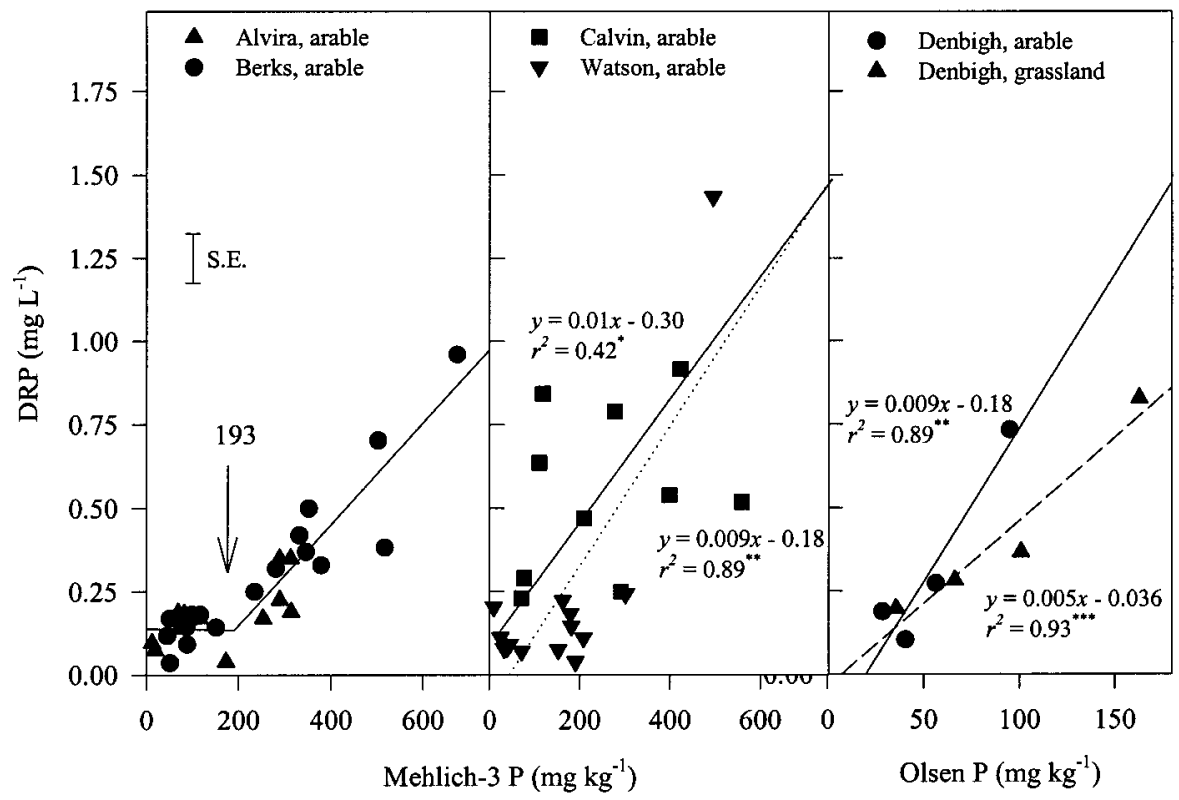

Fig. 5. Relationship between concentrations of dissolved reactive phosphorus (DRP) in drainage water from lysimeter and topsoil (0-7.5 cm) soil test phosphorus (STP) of the FD-36 and Denbigh arable and grassland soils. The change point is indicated by the arrow. $r^{2}$ is the coefficient of determination. S.E. is the standard error.

These soils were selected to have a range of concentrations and means similar to those in Table 1 . As expected, the concentration of DRP in surface runoff increased with STP concentration in all soils (Fig. 7). At high Mehlich-3 $\mathrm{P}$ concentrations $\left(>185 \mathrm{mg} \mathrm{kg}^{-1}\right)$ and Olsen $\mathrm{P}\left(>35 \mathrm{mg} \mathrm{kg}^{-1}\right)$, concentrations of DRP in the first 250 $\mathrm{mL}$ of surface runoff increased much more relative to STP, indicating a change point. A change point in Mehlich-3 $\mathrm{P}$ concentration was also evident in a subsample of all surface runoff combined (including additional data for Berks arable soils). However, this relationship was also adequately described $(P<0.01)$ by a linear regression (Fig. 7). Concentrations of DRP in subsamples of all surface runoff combined from Denbigh arable and grassland soils were linearly related to Olsen $\mathrm{P}$ concentration (Fig. 7).

Hesketh and Brookes (2000) showed that as the soil to solution ratio widens the concentration of $\mathrm{CaCl}_{2}-\mathrm{P}$ decreases, but the change point remains constant. They used this to explain the different slopes in plots of DRP concentration in drainage water against Olsen $\mathrm{P}$ concentration following rainfall of different intensities. In the present study, suspended sediment and $\mathrm{Ca}$ were determined in the first $250 \mathrm{~mL}$ of surface runoff and all surface runoff combined for a representative range of Mehlich-3 P concentrations for each soil. The ratios of suspended sediment to solution in all surface runoff combined were greater than those in the first $250 \mathrm{~mL}$ of surface runoff (Table 4). Effectively, decreasing the slope of DRP concentration in surface runoff relative to STP concentration made it harder to determine a change point.

Like DRP, mean concentrations of $\mathrm{Ca}^{2+}$ were greater in the first $250 \mathrm{~mL}$ of surface runoff than in a sample of all surface runoff combined, probably the result of the selective erosion of fine clay particles (Sharpley, 1985) and the smaller soil to solution or sediment to runoff ratio (Table 5). Increasing ionic strength is known to decrease P desorption (Evans and Sorensen, 1986). However, the higher concentration of Ca may make the

Table 4. Means and range $(w)$ of organic $\mathbf{C}$, $\mathbf{p H}$, and concentration of Olsen $\mathbf{P}$, Mehlich-3 $\mathbf{P}$, and $\mathrm{CaCl}_{2}-\mathbf{P}$ for the $\mathrm{Slapton}_{\mathbf{W o o d}}$ (Denbigh) and FD-36 (Alvira, Berks, Calvin, and Watson) soils used in the surface runoff boxes.

\begin{tabular}{|c|c|c|c|c|c|}
\hline Site & Organic C & pH & Olsen P & Mehlich-3 P & $\mathrm{CaCl}_{2}-\mathbf{P}$ \\
\hline \multicolumn{3}{|c|}{$\mathrm{g} \mathrm{kg}^{-1}$} & \multicolumn{2}{|c|}{$\mathrm{mg} \mathrm{P} \mathrm{kg}^{-1}$} & $\operatorname{mg} \mathbf{P} \mathbf{L}^{-1}$ \\
\hline Denbigh arable & $32(1) \dagger$ & $6.1(0.1)$ & $38(4.0)$ & nd $\$$ & $0.31(0.020)$ \\
\hline$w$ & $29-36$ & $5.7-6.6$ & 8-74 & - & $0.05-0.75$ \\
\hline Denbigh grassland & $54(4)$ & $5.3(0.2)$ & $31(3.0)$ & nd & $0.52(0.020)$ \\
\hline$w$ & 34-74 & $5.2-5.7$ & 4-61 & - & $0.16-0.89$ \\
\hline Alvira arable & 19 (5) & $6.0(0.1)$ & $22(3.0)$ & $97(25)$ & $0.30(0.030)$ \\
\hline$w$ & 15-20 & $5.6-6.4$ & 6-62 & 29-215 & $0.13-0.44$ \\
\hline Berks arable & $21(5)$ & $6.3(0.1)$ & $43(3.4)$ & $319(31)$ & $0.52(0.080)$ \\
\hline$w$ & 17-25 & 5.4-6.7 & $8-71$ & $5-726$ & $0.07-1.74$ \\
\hline Calvin arable & nd & $6.6(0.2)$ & $41(5.0)$ & $264(25)$ & $0.47(0.080)$ \\
\hline$w$ & - & $5.5-7.1$ & $26-84$ & $155-411$ & $0.26-1.53$ \\
\hline Watson arable & $18(3)$ & $6.1(0.1)$ & 15 (4.1) & 107 (9) & $0.30(0.074)$ \\
\hline$w$ & 15-20 & $5.7-6.6$ & $8-58$ & 58-247 & $0.10-0.95$ \\
\hline
\end{tabular}

$\dagger \pm$ standard error.

$\neq$ nd $=$ not determined. 


\section{Lysimeter drainage waters}

\section{Surface runoff}

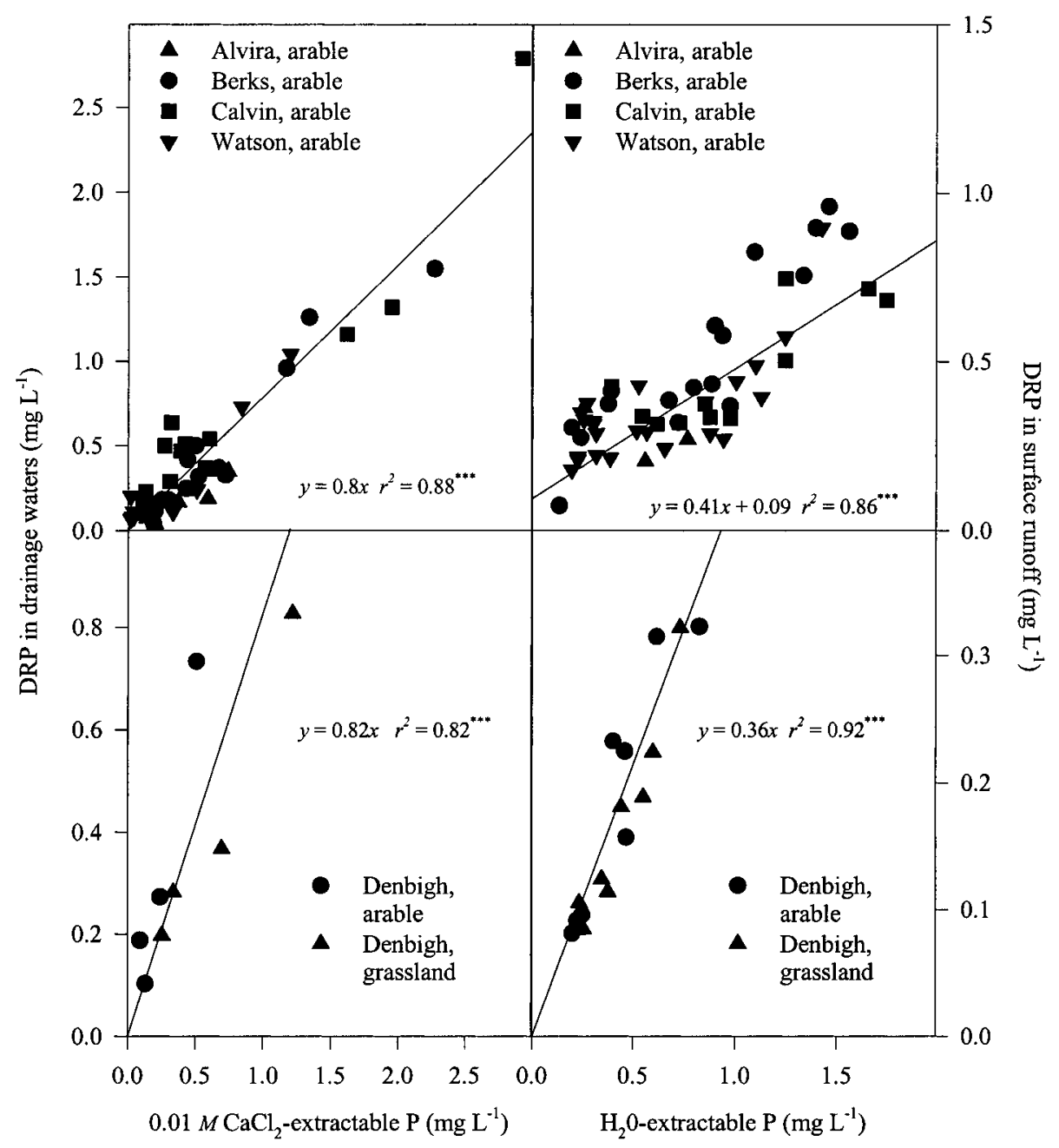

Fig. 6. Relationship between dissolved reactive phosphorus (DRP) in drainage water from lysimeters or in all surface runoff against $0.01 M$ $\mathrm{CaCl}_{2}-$ or water-extractable $\mathbf{P}$ for the FD-36 and Denbigh soils. $\boldsymbol{r}^{2}$ is the coefficient of determination. $* * *$ indicates significance at the $P<$ 0.001 level.

first $250 \mathrm{~mL}$ of surface runoff behave like a $0.01 \mathrm{M}$ $\mathrm{CaCl}_{2}$ extraction, probably releasing $\mathrm{P}$ from a different and more labile pool to the rest of the surface runoff and making the change point more evident.

More DRP was released into surface runoff from the grassland Denbigh soils over a range of Olsen $\mathrm{P}$ concentrations from 0 to $45 \mathrm{mg} \mathrm{kg}^{-1}$ than from the Denbigh arable soils, although the slope of the linear regression was higher for arable soils than grassland soils (Fig. 7). Similarly, in an adjacent watershed to Slapton Wood, Heathwaite et al. (1990) found that inorganic P concentrations in surface runoff from a lightly grazed grassland plot were greater $(50 \%)$ than those from runoff from an arable plot. Surface runoff from grassland compared with arable plots carries little sediment, and is dominated by DRP (Sharpley and Lord, 1997). The Denbigh grassland soils contain more organic $\mathrm{C}$ and, hence, organic matter than the arable soils (Table 4). While the role organic matter plays in $\mathrm{P}$ desorption is not clear
(Afif et al., 1995), it has been linked to a decrease in $\mathrm{P}$ sorption (Barrow, 1989). By occupying P sorption sites, larger amounts of organic $\mathrm{C}$ in grassland soils may increase the desorption potential of loosely bound $\mathrm{P}$ compared with arable soils. Dils and Heathwaite (1996) showed that a large proportion of the DRP in surface runoff from grassland is in organic forms. Therefore, relative to arable soils, the grassland soils may also have DRP concentrations detected by the Mo reaction of Murphy and Riley (1962) inflated above their real value by the hydrolysis of some loosely bound organic $\mathrm{P}$ forms (Stevens, 1979).

Extraction of topsoil with water has been used in the past to simulate DRP release into surface runoff (e.g., Pote et al., 1996). In general, water extracted twice more DRP than was released into surface runoff. However, a plot of DRP in surface runoff against DRP extracted by water from topsoil $(0-5 \mathrm{~cm})$ shows that the two are significantly related two each other (Fig. 6). Thus, a 


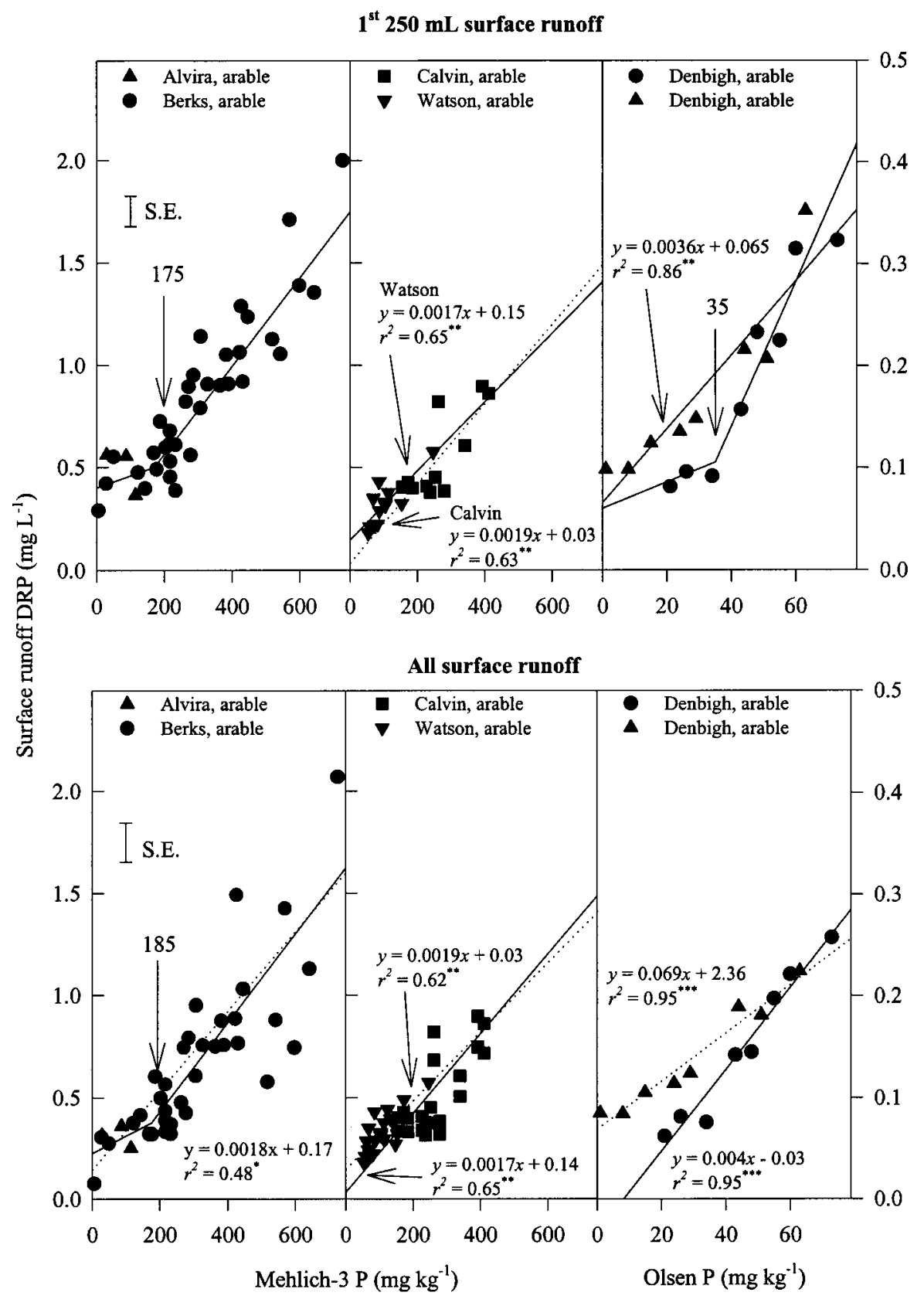

Fig. 7. Relationship between concentrations of dissolved reactive phosphorus (DRP) in the first $250 \mathrm{~mL}$ of surface runoff or all surface runoff combined and soil test phosphorus (STP) for the FD-36 and Denbigh arable and grassland soils. The change point is indicated by the arrow. S.E. is the standard error. $\boldsymbol{r}^{2}$ is the coefficient of determination of the linear regressions. $*$ and $* * *$ indicate significance at the $\boldsymbol{P}<0.05$ and 0.001 levels, respectively.

water extraction at a soil to solution ratio of 1 to 5 may be useful as a predictor of both a change point in STP and an estimator for DRP loss in surface runoff. However, as with $\mathrm{CaCl}_{2}-\mathrm{P}$, a cautious approach should be taken when using water to estimate DRP in surface runoff, as this may vary between soil types and require calibration.

\section{Possible Implications for Management}

Phosphorus concentrations that cause eutrophication can range from 0.01 to $0.03 \mathrm{mg} \mathrm{L}^{-1}$ (Sharpley et al., 1996; USEPA, 1994). Pote et al. (1996) found that a
Mehlich-3 $\mathrm{P}$ concentration of $50 \mathrm{mg} \mathrm{kg}^{-1}$ (optimum for many crops) gave a DRP concentration in overland flow from grassland in Arkansas of $0.5 \mathrm{mg} \mathrm{L}^{-1}$. Sibbesen and Sharpley (1997) reported that an "optimum" Bray-I P concentration of $30 \mathrm{mg} \mathrm{kg}^{-1}$ yielded DRP concentrations in surface runoff from 0.025 to $0.35 \mathrm{mg} \mathrm{L}^{-1}$ in different soils. Thus, soils with STP concentrations similar to those recommended for optimum crop growth, may sustain DRP concentrations in surface runoff above levels accelerating eutrophication in surface water bodies.

However, the change point is often above optimum 
Table 5. Means and range $(w)$ of calcium $\left(\mathrm{Ca}^{2+}\right)$ concentrations and suspended sediment (SS) to volume ratios in the first $250 \mathrm{~mL}$ and all surface runoff combined for the Slapton Wood (Denbigh) and FD-36 (Alvira, Berks, Calvin, and Watson) soils.

\begin{tabular}{|c|c|c|c|c|}
\hline \multirow[b]{2}{*}{ Site } & \multicolumn{2}{|c|}{ First $250 \mathrm{~mL}$ surface runoff } & \multicolumn{2}{|c|}{ All surface runoff combined } \\
\hline & $\mathrm{Ca}^{2+}$ & SS to volume ratio & $\mathbf{C a}^{2+}$ & SS to volume ratio \\
\hline & $\mathbf{m g ~ \mathbf { L } ^ { - 1 }}$ & g $\mathbf{L}^{-1}$ & $\mathbf{m g ~ \mathbf { L } ^ { - 1 }}$ & $\operatorname{g~L}^{-1}$ \\
\hline Denbigh arable & $2.9(0.1) \dagger$ & $2.1(0.2)$ & $1.9(0.1)$ & $0.12(0.04)$ \\
\hline$w$ & 1.9-3.9 & $0.9-2.9$ & $0.8-2.5$ & $0.02-0.28$ \\
\hline Denbigh grassland & $1.6(0.1)$ & $0.2(0.0)$ & $1.0(0.1)$ & $0.01(0.00) \$$ \\
\hline$w$ & $0.9-1.9$ & $0.0-0.3$ & $0.5-1.4$ & $0.00-0.02$ \\
\hline Alvira arable & $2.0(0.2)$ & $7.1(0.2)$ & $1.7(0.0)$ & $0.51(0.20)$ \\
\hline$w$ & $1.7-2.4$ & $6.5-8.2$ & $1.7-1.8$ & $0.41-0.61$ \\
\hline Berks arable & $2.3(0.2)$ & $5.1(0.2)$ & $1.7(0.1)$ & $0.30(0.04)$ \\
\hline$w$ & $1.8-5.0$ & $4.2-6.7$ & $1.4-2.0$ & $0.17-0.71$ \\
\hline Calvin arable & $1.8(0.9)$ & $5.5(0.2)$ & $1.4(0.2)$ & $0.38(0.09)$ \\
\hline$w$ & $1.4-2.1$ & $4.8-5.9$ & 1.1-1.6 & $0.25-0.42$ \\
\hline Watson arable & $2.2(0.1)$ & $7.8(0.3)$ & $1.7(0.1)$ & $0.50(0.06)$ \\
\hline$w$ & $1.7-3.3$ & $5.2-10.2$ & $1.4-2.1$ & $0.14-0.78$ \\
\hline
\end{tabular}

$\dagger \pm$ standard error.

$\uparrow$ Commonly below detection limit of $0.01 \mathrm{~g} \mathrm{~L}^{-1}$.

STP concentration for crop growth. For example, the Broadbalk soil at Rothamsted (Harpenden, UK) has a change point at $55 \mathrm{mg} \mathrm{kg}^{-1}$ Olsen P (Heckrath et al., 1995), well above the optimum Olsen $P$ concentration of $25 \mathrm{mg} \mathrm{kg}^{-1}$ for potatoes, sugar beet, winter wheat, and spring barley (Johnston and Poulton, 1997). Within the FD-36 watershed a Mehlich-3 P of $50 \mathrm{mg} \mathrm{kg}^{-1}$ is seen as adequate for the optimum growth of crops (Beegle, 1999), and is well below the change point of $190 \mathrm{mg}$ $\mathrm{kg}^{-1}$ (Fig. 1). If P management was based on the STP change point, the majority of the soils within the watershed have a Mehlich-3 P less than the change point and therefore are less likely to release $\mathrm{P}$ into surface runoff and subsurface drainage (McDowell et al., 2001). Furthermore, if only those sources of $\mathrm{P}$ that are hydrologically active (i.e., subsurface drainage, high water table, and/or surface runoff contributes to stream flow) are considered, then the area at risk of P loss may be further reduced (Gburek et al., 2000).

Evidence presented here and elsewhere (e.g., Hesketh and Brookes, 2000; McDowell and Condron, 1999) shows that a lab-based extraction of soil solution $\mathrm{P}$ with $0.01 \mathrm{M} \mathrm{CaCl}_{2}$ can yield a change point very similar in magnitude to that between DRP in surface runoff or subsurface drainage water and STP. As the change point is derived from a quantity (Olsen $\mathrm{P})$-intensity $\left(\mathrm{CaCl}_{2}-\mathrm{P}\right)$ relationship or an inverse desorption isotherm, this infers that any existing STP method that attempts to measure the quantity of $\mathrm{P}$ in the soil may be coupled with a measure of $\mathrm{P}$ in soil solution, surface runoff ( $\mathrm{P}$ intensity), or subsurface drainage to establish a change point (McDowell et al., 2001). However, to be useful as a management tool the change point must be able to consistently estimate $\mathrm{P}$ lost in surface runoff and subsurface drainage in different soils and hydrological conditions.

Evidence suggests that while the change point remains constant, the slope of $\mathrm{CaCl}_{2}-\mathrm{P}$ or DRP against STP changes with rainfall intensity as a result of changing ionic strength and soil to solution ratio (Table 5). As the relationship between concentrations of STP and DRP tends toward linearity the change point in STP becomes more difficult to detect. Soils extractions with $0.01 \mathrm{M} \mathrm{CaCl}_{2}$ are designed to best represent the soil solution, and the results have suggested that this is true for subsurface drainage. Water extractions have been used in a number of studies to estimate DRP in surface runoff (e.g., Pote et al., 1996; Sharpley et al., 1996). However, both the soil to solution ratio and ionic strength vary with rainfall intensity and the volume of surface runoff (Sharpley et al., 1986). Thus, in the field, DRP concentrations in surface runoff during a short storm or one carrying a large amount of sediment may be better predicted with $0.01 \mathrm{M} \mathrm{CaCl}_{2}$ than water. Within the FD-36 watershed, a $50 \mathrm{~mm} \mathrm{~h}^{-1}$ storm event lasting for $30 \mathrm{~min}$ will occur on average once every $2.33 \mathrm{yr}$, while a $10 \mathrm{~mm} \mathrm{~h}^{-1}$ storm lasting for 30 min will occur several times a year (Aron et al., 1986). While laboratory extractions with water or $0.01 M \mathrm{CaCl}_{2}$ have shown some ability to estimate DRP concentration in surface runoff and subsurface drainage, respectively, further work is required to determine their behavior to the different rainfall intensities and durations in the field.

\section{CONCLUSIONS}

A plot of $\mathrm{CaCl}_{2}-\mathrm{P}$ or water-extractable $\mathrm{P}$ concentration against STP (Olsen P or Mehlich-3 P) showed a point in STP concentration above which $\mathrm{CaCl}_{2}-\mathrm{P}$ increased at a greater rate per unit increase in STP than if below (i.e., a change point). The change point remained constant in a plot of STP and different $\mathrm{CaCl}_{2}-\mathrm{P}$ extraction times, but disappeared when plotted against water, inferring different pools were being extracted. Similar change points were also observed when STP was related to the DRP concentration of surface runoff or subsurface drainage. The concentration of DRP in drainage waters was significantly related, and of very similar magnitude, to $\mathrm{CaCl}_{2}-$ extractable $\mathrm{P}$ of lysimeter topsoils. Water-extractable DRP was significantly related to DRP in surface runoff, but approximately twice the concentration.

More DRP was present in the first $250 \mathrm{~mL}$ of surface runoff than all the surface runoff combined. A plot of all surface runoff combined against topsoil STP exhibited a higher linear regression correlation coefficient than if plotted against DRP in the first $250 \mathrm{~mL}$ of surface run- 
off. This was attributed to the lesser concentration and soil to solution ratio (or suspended sediment to volume ratio) in all surface runoff combined compared with the first $250 \mathrm{~mL}$ of surface runoff.

Use of water and $0.01 \mathrm{M} \mathrm{CaCl}_{2}$ extraction of surface soil is suggested for the estimation of DRP in surface runoff and subsurface drainage waters, respectively, and for determination of the change point in STP, which may be used in support of agricultural and environmental P management strategies.

\section{REFERENCES}

Afif, E., V. Barrón, and J. Torrent. 1995. Organic matter delays but does not prevent phosphate sorption by Cerrado soils from Brazil. Soil Sci. 159:207-211.

Aron, G., D.J. Wall, E.L. White, C.N. Dunn, and D.M. Kotz. 1986. Field manual of Pennsylvania Dep. of Transportation: Storm intensity-duration-frequency charts. Dep. of Civil Eng. and Inst. for Res. on Land and Water Resour., Pennsylvania State Univ., University Park.

Barrow, N.J. 1989. Testing a mechanistic model. IX. Competition between anions for sorption by soil. J. Soil Sci. 36:187-197.

Barrow, N.J., and T.C. Shaw. 1979. Effects of solution:soil ratio and vigour of shaking on the rate of phosphate adsorption by soil. $\mathrm{J}$. Soil Sci. 30:67-76.

Beauchemin, S., R.R. Simard, and D. Cluis. 1996. Phosphorus sorption-desorption kinetics of soil under contrasting land uses. J. Environ. Qual. 25:1317-1325.

Beegle, D. 1999. Soil fertility management. p. 19-46. In N. Seroktin and S. Tibbetts (ed.) Agronomy Guide 1999-2000. Publ. Distributions Center, Pennsylvania State Univ., University Park.

Birch, H.F. 1964. The effect of 2:4-dinitro-phenol on phosphorus transformations during humus decomposition. Plant Soil 21:391-394.

Breeuwsma, A., and S. Silva. 1992. Phosphorus fertilization and environmental effects in the Netherlands and the Po region (Italy). Rep 57. Agric. Res. Dep., The Winand Staring Centre for Integrated Land, Soil and Water Res., Wageningen, the Netherlands.

Chien, S.H., and W.R. Clayton. 1980. Application of Elovich equation to the kinetics of phosphate release and sorption in soils. Soil Sci. Soc. Am. J. 44:265-268.

Cooperband, L.R., and T.J. Logan. 1992. Measuring in-situ changes in labile soil phosphorus with anion-exchange membranes. Soil Sci. Soc. Am. J. 58:105-114.

Dils, R.M., and A.L. Heathwaite. 1996. Phosphorus fractionation in hillslope hydrological pathways contributing to agricultural runoff. p. 229-252. In M.G. Anderson and S.M. Brooks (ed.) Advances in hillslope processes. Vol. 1. John Wiley \& Sons, Chichester, England.

Elkhatib, E.A., and J.L. Hern. 1988. Kinetics of phosphorus desorption from Appalachian soils. Soil Sci. 145:222-229.

Evans, R.L., and R.C. Sorensen. 1986. The influence of ionic strength and monovalent cation source in a leaching solution of phosphorus extractability in a coarse-textured soil. Soil Sci. 141:38-42.

Foy, R.H., and P.J.A. Withers. 1995. The contribution of agricultural phosphorus to eutrophication. Proc. No. 365. The Fertilizer Soc., Peterborough, England.

Freese, D., R. Lookman, R. Merckx, and W.H. van Riemsdijk. 1995. New method for assessment of long-term phosphate desorption from soils. Soil Sci. Soc. Am. J. 59:1295-1300.

Gburek, W.J., A.N. Sharpley, L. Heathwaite, and G.J. Folmar. 2000. Phosphorus management at the watershed scale: A modification of the phosphorus index. J. Environ. Qual. 29:130-144.

Genstat 5 Committee. 1995. Genstat 5 Release 3 reference manual. Clarendon Press, Oxford, England.

Grewal, K.S., G.D. Buchan, and R.R. Sherlock. 1991. A comparison of three methods of organic carbon determination in some New Zealand soils. J. Soil Sci. 42:251-257.

Hanway, J.J., and J.M. Laflen. 1974. Plant nutrient losses from tileoutlet terraces. J. Environ. Qual. 25:727-732.

Heathwaite, A.L., T.P. Burt, and S.T. Trudgill. 1990. The effect of land use on nitrogen, phosphorus, and suspended sediment delivery to streams in a small catchment in southwest England. p. 161-177. In J. Thornes (ed.) Vegetation and erosion. John Wiley \& Sons, Chichester, England.

Heckrath, G., P.C. Brookes, P.R. Poulton, and K.W.T. Goulding. 1995. Phosphorus leaching from soils containing different phosphorus concentrations in the Broadbalk experiment. J. Environ. Qual. 24:904-910.

Hesketh, N., and P.C. Brookes. 2000. Development of an indicator for risk of phosphorus leaching. J. Environ. Qual. 29:105-110.

Johnston, A.E., and P.R. Poulton. 1997. Defining critical levels of available soil phosphorus for agricultural crops. p. 441-445. In $\mathrm{H}$ Tunney et al. (ed.) Phosphorus loss from soil to water. CAB Int. Press, Oxon, England.

Lookman, R., D. Freese, R. Merckx, K. Vlassak, and W.H. van Riemsdijk. 1995. Long-term kinetics of phosphate release from soils. Environ. Sci. Technol. 29:1569-1575.

McDowell, R.W., and L.M. Condron. 1999. Developing a predictor for phosphorus loss from soil. p. 153-164. In L.D. Currie (ed.) Best soil management practices for production. Fertilizer and Lime Res. Centre 12th Annual Workshop, Palmerston North, New Zealand. 10-13 Feb. 1999. Massey Univ., Palmerston North, New Zealand.

McDowell, R.W., A.N. Sharpley, P.J.A. Kleinman, and W.J. Gburek 2001. Hydrological and source management of pollutants at the soil profile scale. In P.M. Haygarth and S.C. Jarvis (ed.) Agriculture, hydrology and water quality. CAB Int. Press, Oxon, England (in press).

McDowell, R.W., and S.T. Trudgill. 2000. Variation of phosphorus loss from a small catchment in south Devon, U.K. Agric. Ecosyst. Environ. 79:143-157.

McKeague, J.A., and J.H. Day. 1966. Dithionite and oxalate-extractable $\mathrm{Fe}$ and $\mathrm{Al}$ as aids in differentiating various classes of soils. Can. J. Soil Sci. 46:13-22.

Mehlich, A. 1984. Mehlich-3 soil test extractant: A modification of Mehlich-2 extractant. Commun. Soil Sci. Plant Anal. 15:1409-1416.

Murphy, J., and J.R. Riley. 1962. A modified single solution method for the determination of phosphate in natural waters. Anal. Chim. Acta 27:31-36.

Olsen, S.R., C.V. Cole, F.S. Watanabe, and L.A. Dean. 1954. Estimation of available phosphorus in soils by extraction with sodium bicarbonate. USDA Circ. 939. U.S. Gov. Print. Office, Washington, DC.

Polyzopoulos, N.A., V.Z. Keramidas, and A. Pavatou. 1986. On the limitations of the simplified Elovich equation in describing the kinetics of phosphate sorption and release from soils. J. Soil Sci. 37:81-87.

Pote, D.H., T.C. Daniel, A.N. Sharpley, P.A. Moore, Jr., D.R. Edwards, and D.J. Nichols. 1996. Relating extractable soil phosphorus to phosphorus losses in runoff. J. Environ. Qual. 60:855-859.

Raven, K.P., and L.R. Hossner. 1994. Phosphorus desorption kinetics and its relationship with plant growth. Soil Sci. Soc. Am. J. 58: 416-423.

Ryden, J.C., and J.K. Syers. 1975. Rationalization of ionic strength and cation effects on phosphate sorption by soils. J. Soil Sci. 26:395-406

Schofield, R.K. 1955. Can a precise meaning be given to 'available' soil phosphorus. Soils Fert. 18:373-375.

Sharpley, A.N. 1985. The selective erosion of plant nutrients in runoff. Soil Sci. Soc. Am. J. 49:1527-1534.

Sharpley, A.N., L.R. Ahuja, R.G. Menzel. 1981. The release of soil phosphorus to runoff in relation to the kinetics of desorption. J. Environ. Qual. 10:386-391.

Sharpley, A.N., T.C. Daniel, J.T. Sims, and D.H. Pote. 1996. Determining environmentally sound soil phosphorus levels. J. Soil Water Conserv. 51:160-166.

Sharpley, A.N., B. Foy, and P. Withers. 2000. Practical and innovative measures for the control of agricultural phosphorus losses to water: An overview. J. Environ. Qual. 29:1-10.

Sharpley, A.N., and E.J. Lord. 1997. The loss of nitrogen and phosphorus in agricultural runoff: Processes and management. p. 548-563. In O. van Cleemput et al. (ed.) Fertilization for sustainable plant production and soil fertility. 11th Int. World Fertilizer Congress, Gent Univ., Gent, Belgium. 7-13 Sept. 1997. Federal Agric. Res. Centre, Braunschweig-Völkenrode, Germany.

Sharpley, A.N., S.J. Smith, and R.G. Menzel. 1986. Phosphorus criteria and water quality management for agricultural watersheds. p. 177- 
182. In Proc. 5th Annu. Conf. Int. Symp. Appl. Lake Watershed Manage., Lake Geneva, WI. 13-16 Nov. 1985. North Am. Lake Manage. Soc., Lake Geneva, WI.

Sharpley, A.N., R.W. Tillman, and J.K. Syers. 1977. Use of laboratory extraction data to predict losses of dissolved inorganic phosphate in surface runoff and tile drainage. J. Environ. Qual. 6:33-36.

Shelton, C.H., R.D. von Bernuth, and S.P. Rajbhandari. 1985. A continuous-application rainfall simulator. Trans. ASAE 28:11151119.

Sibbesen, E., and A.N. Sharpley. 1997. Setting and justifying upper critical limits for phosphorus in soils. p. 151-176. In H. Tunney et al. (ed.) P loss from soil to water. CAB Int. Press, Oxon, England.
Smith, K.A., A.G. Chalmers, B.J. Chalmers, and P. Christie. 1998. Organic manure phosphorus accumulation, mobility and management. Soil Use Manage. 14:154-159.

SPSS. 1993. SPSS Version 6.0. SPSS, Chicago, IL.

Stevens, R.J. 1979. Evaluation of an enzymatic method for orthophosphate determination in freshwaters. Water Res. 13:767-770.

USEPA. 1994. Water quality standards handbook. 2nd ed. EPA $823-$ B-94-005a. USEPA Office of Water, Washington, DC.

Vig, A.C., and G. Dev. 1979. Kinetics of phosphate desorption in soils. J. Nucl. Agric. Biol. 8:62-66.

Withers, P.J.A., and S.C. Jarvis. 1998. Mitigation options for diffuse phosphorus loss to water. Soil Use Manage. 10:348-354.

\title{
Organic Compounds in the Environment
}

\section{On the Interaction Mechanisms of Atrazine and Hydroxyatrazine with Humic Substances}

\author{
Ladislau Martin-Neto,* Dinis Gomes Traghetta, Carlos M. P. Vaz, Silvio Crestana, and Garrison Sposito
}

\begin{abstract}
Atrazine (6-chloro- $\mathrm{N}^{2}$-ethyl- $\mathrm{N}^{4}$-isopropyl-1,3,5-triazine-2,4-diamine) is retained against leaching losses in soils principally by sorption to organic matter, but the mechanism of sorption has been a matter of controversy. Conflicting evidence exists for proton transfer, electron transfer, and hydrophobic interactions between atrazine and soil humus, but no data are conclusive. In this paper we add to the database by investigating the role of (i) hydroxyatrazine (6-hydroxy- $N^{2}$-ethyl$N^{4}$-isopropyl-1,3,5-triazine-2,4-diamine) and (ii) hydrophobicity in the sorption of atrazine by Brazilian soil humic substances. We demonstrate, apparently for the first time, that hydroxyatrazine readily forms electron-transfer complexes with humic substances. These complexes probably are the cause of the well-known strong adsorption by humic acids and they may be the undetected cause of apparent electrontransfer complexes between soil organic matter and atrazine, whose transformation to the hydroxy form is facile. We also present evidence that supports the important contribution of hydrophobic interactions to the $\mathbf{p H}-d e p e n d e n t$ sorption of atrazine by humic substances.
\end{abstract}

A RAZINE is used widely for the control of broadleaf and grassy weeds on both agricultural and nonagricultural land. Unfortunately, it is also very widely detected in water supplies (Thurman et al., 1991, 1992; Ritter et al., 1994; Tindall and Vencill, 1995; Goolsby et al., 1997; Kolpin et al., 1998; Clark et al., 1999). For this reason, atrazine is considered to be an important environmental contaminant, with potential carcinogenic effects of $s$-triazines being of growing concern in water quality management (Birardar and Rayburn, 1995). Offsite movement of atrazine can be prevented, however, through an understanding of its fate in the soil environ-

L. Martin-Neto, C.M.P. Vaz, and S. Crestana, Embrapa Instrumentação Agropecuária, C.P. 741, 13560-970 São Carlos (SP), Brazil; D.G. Traghetta, Centro Universitário Positivo, Av. Nossa Senhora Aparecida, 174, 80440-000 Curitiba (PR), Brazil; and G. Sposito, Ecosystem Sciences, Hilgard Hall \#3110, Univ. of California, Berkeley, CA 94720 3110. Received 20 Mar. 2000. *Corresponding author (martin@cnpdia. embrapa.br).

Published in J. Environ. Qual. 30:520-525 (2001). ment (Racke et al., 1997), which includes both degradation (20-150 d half-life) and retention by soil humus (Koskinen and Clay, 1997).

The mechanism of atrazine sorption by soil organic matter has been a topic of considerable controversy. Early work (Weber et al., 1969; Hayes, 1970) showed that sorption was inhibited by the low $\mathrm{p} K_{\mathrm{a}}$ (1.68) of the herbicide molecule, with proton transfer between it and carboxyl groups at low $\mathrm{pH}$ proposed as the probable mechanism of retention by organic colloids. Wang et al. $(1990,1991)$ presented adsorption envelopes for atrazine on humic substances that support this mechanism, in that they exhibited sharp peaks at $\mathrm{pH} \leq 3$, depended strongly on the extent of carboxyl protonation, and were diminished in the presence of metal cations (see also Gamble et al., 1994). Martin-Neto et al. (1994) and Sposito et al. (1996) provided additional experimental support through infrared spectra demonstrating an increased content of carboxylate species in atrazinehumic acid adducts. Moreover, they also concluded, in agreement with theoretical studies by Welhouse and Bleam (1993a,b), that the electron-donating capability of atrazine usually was not sufficient to engage an electron-transfer complexation mechanism with humic acids.

Senesi (1992), on the other hand, had proposed electron transfer between the triazine ring (or the amino groups) in atrazine and quinone-like moieties in humic acid as a principal mechanism of sorption, reasoning that such complexes would be stabilized as semiquinone species by the complex molecular structure of humic acid. Piccolo et al. (1992), Senesi et al. (1995), and Sposito et al. (1996) indeed have found this mechanism (as evidenced usually by an increase of semiquinone free radical content in atrazine-humic acid adducts) to operate in some instances. Sposito et al. (1996) have hypothe-

Abbreviations: AT, atrazine; ESR, electron spin resonance; FA, fulvic acid; FTIR, Fourier-transform infrared; HA, humic acid; HYAT, hydroxyatrazine. 